\title{
A SYSTEMATIC APPROACH FOR ERP IMPLEMENTATION IN THE CONSTRUCTION INDUSTRY
}

\author{
Laith HADIDI, Sadi ASSAF, Adel ALKHIAMI \\ Construction Engineering and Management Department, College of Environmental Design, King Fahd \\ University of Petroleum and Minerals, Eastern Province, Dhahran 31261 and Saudi Arabia
}

Received 15 Feb 2016; accepted 10 Jun 2016

\begin{abstract}
The objective of this paper is to provide a decision support tool that helps in prioritizing enterprise resource planning (ERP) modules' implementation. The literature shows high risks of failure during the ERP implementation in construction industry. This research provides a systematic approach to have a successful ERP implementation in the construction industry. The provided approach of this research helps construction companies worldwide and specifically Saudi Arabia to better implement ERP projects. A case study approach is conducted with experts in ERP implementation at construction field in order to rank different ERP modules. This research develop a four step methodology to sequence the ERP module implementation. The first step defines the most common ERP modules in the construction industry. The second step defines the expected benefits of ERP implementation. The third step will define the importance index (I). Finally, the fourth step rank the ERP modules based on the global index that combines the criteria index and module index. The main findings of this research provided a comprehensive list of thirteen ERP modules ranked according to the Saudi construction industry. Out of thirteen modules, the top ranked modules were inventory control and logistics, procurement, and project finance and accounting.
\end{abstract}

Keywords: automation in construction, enterprise resource planning, logistics, procurement, finance, construction management.

\section{Introduction}

Enterprise resource planning (ERP) is seen as an expensive investment for architectural and construction companies. ERP is an integral software that is spanning to cover all organization functions with one shared database that increase information sharing and integrity of business processes. ERP is deployed in a form of internal company project usually with multi-years delivery plan depending on the size of company and number of selected ERP modules. ERP deployment needs dedication of a large portion of the company resources. In addition, it usually requires re-engineering of company work processes; train the staff for operation and upgrading the IT infrastructure. Construction engineering and management experts asserted in the 1980s that computer-based information and communication technologies (ICTs) would grow quickly to increase the efficiency of communications in the architecture, engineering, and construction (AEC) industry (Arnold, Javernick-Will 2013).

ERP is noticeably deployed successfully in manufacturing and trading firms. In contracting domain and more specifically in construction field, due to complexity of business environment and uniqueness aspects of each project/client, the time and cost required to deploy a full scale ERP projects are higher than other fields with a higher failure rate in reported deployment projects. Hence, assessing the risk of ERP implementation failures is encouraged to be assessed prior to deployment. Ghosh and Skibniewski (2010) provided a focus study on the critical success factors (CSF) and risk factors (RF) to help organizations in ERP implementation. In a similar study, Zeng and Skibniewski (2013) proposed a probabilistic risk assessment approach for ERP system implementation projects based on fault tree analysis, which models the relationship between ERP system components and specific risk factors. Indeed, better risk management will help organizations to increase the likelihood for ERP implementation success. Isikdag et al. (2013) stated that ERP implementations within large scale construction organizations have yielded more failures than successes. Similarly, the Small- to Mid-Size Construction Organizations (SMSCOs) organizations may also have high risks to fail ERP implementation (Negahban et al. 2012). Studies that have identified several prohibitive factors in ERP implementation, are limited in both their nature and their findings (Skibniewski, Ghosh 2009; Chung et al. 2008). Chung and Skibniewski (2007)

Corresponding author: Laith Hadidi

E-mail: lhadidi@kfupm.edu.sa; laith.alhadidi@gmail.com 
explained that the management of construction companies are faced with many fundamental questions when they start to implement the ERP system related to the functionality of the implemented system. While integrated benefit of ERP would be maximized when deploying all selected functional modules of ERP, prioritizing deployment of these modules having the highest benefit impact may increase significantly the deployment success rate. These benefits encompass information technology infrastructure and strategic, operational, organizational, and managerial aspects of the firm (Tatari, Skibniewski 2011).

This research mainly proposes a four-step methodology for ERP implementation of the most-common used ERP modules in construction field based on the users' benefits. The research collects the experts input through a semi-structured interview survey. This proposed approach will help contracting or construction firms, in future ERP deployments, to prioritize ERP modules at early deployment phases that are interested in partial implementation of ERP packages, to select the most beneficial ERP modules. The results were refined and verified by experts in ERP deployment at construction field and then tailored to the specific needs of the construction market in Saudi Arabia. The findings of this paper help construction companies to: have a better understanding of ERP implementation in construction field and to raise the success rate of ERP deployment.

\section{Literature review}

Yang et al. (2007) developed a case study on the selection of system suppliers and contract negotiation during the ERP implementation of a local construction company in Taiwan in which seven issues were discussed. The issues are based on reviewing the common key success factors in the literature, which defined as: coding system, working process reengineering, priority of ERP functionality implementation, customization, participant roles, consultant role and performance level of subcontractor, which also affected the implementation. They suggests that additional case studies are necessary for the successful application of ERP systems in the construction industry. It was found that there is no a predefined priority for ERP modules and companies need to make their own evaluation.

ERP systems are an increasingly important source of organizational change with major implications for the organization and management of work. Tambovcevs (2012) presented a case study of ERP systems implementation in international construction materials procurement and purchasing company in Latvia. Specifically, this paper briefly described the business processes involved in the manufacturing and construction company and illustrated how ERP systems could be implemented. For an international company, the headquarters' successful experience can provide a guideline to assist the local office to implement new system effectively and efficiently. ERP information system supports manufacturing process and construction object related information.

Hallikainen et al. (2009) presented a general level conceptual framework to sequence ERP module implementations and expand the model to a more detailed level in a case study. The priorities for the implementation sequence of the ERP modules are determined in the case study.

Lu et al. (2014) presents an in-depth review of mainstream studies of information and communication technology (ICT) -supported architectural, engineering, and construction (AEC) organizations published in last 15 years (1998-2012). A total of 145 articles from 12 construction and IT-related journals are identified and have been thoroughly reviewed. This review is divided into four parts: (1) synthesis and general trend of existing literature; (2) lessons learned from ICT practical implementation; (3) enabling technologies of ICT applications; and (4) ICT-induced organizational outcomes. Lu et al. (2014) can become a foundation for the classification and integration of the state of the art in ICT research on behalf of AEC organizations.

Skibniewski and Ghosh (2009) addressed the areas of business processes within the engineering construction industry where ERP cannot be used to collect key performance indicators (KPIs) related to business processes. A survey focused on qualitative aspects of ERP systems implementation in engineering construction firms was conducted among ERP-enablers in the construction industry from major engineering and construction firms in the United States. Different types of KPIs were identified based on two dimensions-knowledge specificity and time specificity. Isikdag et al. (2013) investigated the role of ERP systems in enabling and facilitating data level integration (DLI) in construction industry organizations. An ERP DLI capability matrix was developed as the metric for measuring the capability of ERP systems in enabling DLI. The matrix is validated with four case studies.

Ozorhon and Cinar (2015) explored the critical success factors (CSFs) of ERP implementation in the construction industry. A fourteen CSFs were identified and a questionnaire survey was conducted to analyze the role of those CSFs on the performance of ERP implementation. The data is collected from 90 construction firms from Turkey. The statistical analysis results show that top management support and commitment, clear goals and objectives, project team competence, effectiveness of the project leader, and cooperation between team members are the most significant drivers of success. Findings are expected to help senior managers and consultants implement ERP systems in construction firms.

Karimi et al. (2007) examined why some firms benefit more from ERP implementation than others. ERP implementation from a technological diffusion perspective is investigated under what contextual conditions the extent of ERP implementation has the greatest effect on business process outcomes. It was found that the extent of ERP implementation influences business process outcomes, 
and both ERP radicalness and delivery system play moderating roles. Ram et al. (2014) developed a model with data from a survey of 217 Australian organizations, using structural equation modelling (SEM). It was found that organizations can best achieve competitive advantage by carefully managing: a) training and education, and b) system integration activities. Ehiea and Madsenb (2005) reported the results of an empirical research on the critical issues affecting successful ERP implementation. Through the study, eight factors were identified that attempts to explain $86 \%$ of the variances that impact ERP implementation, namely: project management principles, feasibility/ evaluation of ERP project, human resource development, process re-engineering, top management support, cost/ budget, IT infrastructure, and consulting services. Méxas et al. (2012) surveyed the literature for best ERP selection criteria and suggested analytical hierarchical process (AHP). After validation of these criteria by a group of information technology specialists, a field survey was developed based on the administration of a questionnaire and the use of the analytic hierarchy process. This survey enabled to perform an analysis of the judgment consistency of the 11 respondents who participated in this study and to capture their perceptions of criteria importance. Lee and Yu (2012) developed a project management information system PMIS success model using a questionnaire instrument remitted to experienced users (CMs and constructors), and 253 completed questionnaires were retrieved. The developed model provide users with a useful framework for evaluating PMIS success. Tatari and Skibniewski (2011) used statistical analysis to quantify the critical success factors that impact construction enterprise information systems (CEIS) integration and the ensuing benefits. The model assesses the effects of CEIS induced benefits on user satisfaction and provides a CEIS implementation guide map for construction firms. Dezdar and Ainin (2011) provided a taxonomy of ERP implementation success measures was developed based on the literature. Eleven success measures were identified, namely: Organisational impact, ERP user satisfaction, ERP usage, ERP project schedule, ERP project budget, ERP project goals, System quality, Individual impact, Information quality, Service quality, and Workgroup impact. The success factors span fur categories: ERP user, system, organization and ERP project.

Méxas and Quelhas (2012) made an extensive literature survey to identify the most common used ERP selection criteria, namely: financial, business, software, technological and vendor. Méxas and Quelhas (2012) define the EPR as a system that covers all functional areas and business processes. In manufacturing environment, the Gatner Group is the first who used the term ERP to describe the next generation of MRP (manufacturing resource planning) software in 1990 (Nazemi et al. 2012). Although, ERP implementation was originated in manufacturing environment, implementation has been extended to other industries such as construction industry. Indeed, successful ERP implementation will help the construction to achieve high levels of efficiency in handling contracts and designs. However, the construction business is known to have a very complex environment (due to broad scope of specialties, different company sizes, strategic intend, years of operations, level of IT maturity and many other factors). ERP deployment projects are known to be difficult investments because of implementation complexity and high associated risks of failure (Tambovcevs 2012). While some researches concentrated on ERP vendor selection at the acquisition phase deployment; others focused on implementation phase (implementation methods, problems, success factors and success indicators for ERP deployment). Tambovcevs (2012) addressed both phases (acquisition and implementation).

Huang and Fisher (2005) proposed an analytical framework under TPC paradigm (technology, process and culture as main criteria classes) as a selection criteria for ERP software alternatives. Analytic network process (ANP) technique is utilized to analyze the criteria mutual relations. Although this method is little lengthy and difficult it will facilitate complex IT selection decisions. Içtenbas et al. (2012) emphasized that the selection of right ERP system is a very critical decision for companies as complexity of ERP (system package and vendor) is very high and many alternatives are available. In general, there is overlook at research body regarding partial acquisition of ERP in term of modules selection criteria. The integrated systems in the construction sector present a set of unique challenges, different from those in the manufacturing or other service sectors (Chung et al. 2009).

There have been many cases of failure in implementing ERP systems in the past, so it is critical to identify and understand the factors that largely determine the success or failure of ERP implementation in the construction industry. Chung et al. (2009) presented the process of developing an ERP systems success model to guide a successful ERP implementation project and to identify success factors for ERP systems implementation. Chung et al. (2009) identified factors associated with the success and failure of ERP systems, and develops a success model to analyze the relationships between key factors and the success of such systems. The goal of the ERP systems success model is to better evaluate, plan, and implement ERP projects and help senior managers make better decisions when considering ERP systems in their organization. Wei (2008) proposed a comprehensive framework, through a real-world example, for assessing the performance of an adopted ERP system in a manufacturing environment. Based on the knowledge of ERP implementation objectives, the framework can systematically identify the appropriate ERP performance indicators, construct the performance indicator structure, and set up consistent evaluation standards for facilitating the complex ERP performance evaluation process.

Upon selecting the ERP system package and vendor; an action plan which prioritizes ERP deployment 
within available resources is required at the implementation phase. Many studies concentrate on analyzing the success factors of ERP implementation and the success indicators to measure the implementation success. Mukti et al. (2014) highlights the need for success measurement system for ERP, the study differentiates between success factors and indicators, and it identifies some success indicators such as system/information/service quality, individual/workgroup/organizational impact, system use, user satisfaction, net value which can be used as criteria to assess the success of ERP. Voordijk et al. (2003) conducted a case study in large Dutch construction firm showing that the success of ERP implementations depends on consistent patterns between: IT strategy and business strategy, IT maturity and the strategic role of IT and the implementation method and organizational change. If company strategy is cost reduction, the ERP is less likely to succeed. Mohandas et al. (2013) conducted a survey study to evaluate relevancy of ten success factors of ERP implementation in construction firms, it is found that job relevance is the most important factor. Consultant support is identified as moderate factor highlighting the importance of consultation on ERP projects. Mabert et al. (2003) identified the big-bang approach (ERP package with all its modules are implemented at one time). While implementing few modules together is called the mini big-bang, phased-in approach called when implementing single modules in specific sequence.

In manufacturing, Mabert et al. (2003) also investigated that $17.1 \%$ of US manufacturing companies phased their ERP implementation by module. Similar result $17.3 \%$ is obtained by Olhager and Selldin (2003) for Swedish companies. This highlights that ERP module prioritizing/sequencing is a relevant research problem. No similar survey found on construction companies. Hallikainen et al. (2009) proposed a framework to guide companies in prioritizing modules implementation. This ERP module implementation sequence decision is very important as it ensure the alignment between organizational and technical issues. Although, Hallikainen et al. (2009) framework is a good general tool that can be implemented at any industry; the tool doesn't provide any expert input from the field and subject to implementer own experience and judgment.

As shown in the literature, the selection of ERP software modules and their sequencing during the implementation phase is critical for the success of ERP projects. In this paper we will propose an approach that helps in module selection and sequencing based on experts' inputs from construction domain. This approach will assist firms in proper implementation of selected ERP modules in sequence. Table 1 shows the summary of the research in ERP implementation.

\section{Research methodology}

In general, the research methodology in ERP implementation follows qualitative methods that depend on field work, surveys, case studies, etc. Qualitative approach provides a valuable information and deep insight into the phenomenon under study. However, data collection is time consuming and hence more expensive than quantitative methods but it is highly recommended to study phenomena that spans a wide range of practices in complex industries (Yin 2003). Usually, the main qualitative methods to collect information are: individual interviews (unstructured, semi structured or structured), focus groups, and observations. This research proposes the case study approach based on semi structured interviews methodology to study the ERP implementation in construction industry, Saudi Arabia. The case study method has been proven a useful tool in investigating the problems of ERP implementation (Yang et al. 2007). This approach fits in situation when "how" and "why" questions are being posed, and the researcher has little control over events. The case study can be approached in any of three types: exploratory, explanatory and descriptive. This research has an exploratory question to investigate the common ERP modules used in Saudi construction industry. As shown, many researchers advocate to find implementation approaches to minimize the risk of failure (Ghosh, Skibniewski 2010; Zeng, Skibniewski 2013). In addition, it is seen that implementing the ERP modules in sequence will have better chances to success over the full fledge approach (Hallikainen et al. 2009). Hence, the demand for a decision model to select the sequence of implementation is justified to enable interested construction companies to rank ERP modules implementation. This paper proposes a decision model developed in four steps as follows (Fig. 1):

- First step: Identify common-used ERP Modules in construction and validate it by experts;

- Second step: Identify benefit evaluation criteria and validate it by experts. Six benefit evaluation criteria of ERP modules (Chung, Skibniewski 2007) are validated by the same ERP experts, namely: 1 - cost reduction; 2 - increased efficiency; 3 - improved decision making; 4 - improved information quality; 5 - improved user satisfaction; 6 - improved organizational flexibility;

- Third step: Evaluate the ERP Modules against each benefit criteria using the importance index;

- Fourth step: The overall ranking of ERP Modules is found by calculating the total weight for ERP modules (global index).

\section{Case study}

Saudi Arabia is one of the largest oil producing countries in the world which enabled public and private sectors to invest large sum of money in infrastructure mega projects costing hundreds of billions of US dollars (reference). Saudi construction industry follow the world class practices in construction industry as many of the major construction companies have joint ventures with multinational construction companies. Hence, the Saudi 
Table 1. Literature review summary

\begin{tabular}{|c|c|}
\hline Yang et al. (2007) & A case study on the selection of ERP system suppliers in Taiwan. \\
\hline Tambovcevs (2012) & A case study of ERP systems implementation in materials procurement in Latvia. \\
\hline Hallikainen et al. (2009) & A conceptual framework to sequence ERP module implementations. \\
\hline Lu et al. (2014) & $\begin{array}{l}\text { A review information and communication technology (ICT) in construction published in last } \\
15 \text { years (1998-2012). }\end{array}$ \\
\hline Skibniewski and Ghosh (2009) & $\begin{array}{l}\text { A survey on ERP systems implementation in engineering construction firms among ERP- } \\
\text { enablers in construction firms in the United States. }\end{array}$ \\
\hline Isikdag et al. (2013) & $\begin{array}{l}\text { A model on ERP capability matrix was developed as the metric for measuring the capability } \\
\text { of ERP systems. }\end{array}$ \\
\hline Ozorhon and Cinar (2015) & $\begin{array}{l}\text { A survey of critical success factors (CSFs) of ERP implementation in the construction firms } \\
\text { in Turkey. }\end{array}$ \\
\hline Karimi et al. (2007) & A survey on the benefits of ERP implementation in business. \\
\hline Ram et al. (2014) & $\begin{array}{l}\text { A conceptual model based on critical success factors (CSFs) of ERP implementation of } \\
\text { Australian organizations. }\end{array}$ \\
\hline Ehiea and Madsenb (2005) & An empirical study critical success factors (CSFs) of ERP implementation. \\
\hline Méxas et al. (2012) & A selection model for ERP modules based on literature survey of best selection criteria. \\
\hline Lee and $\mathrm{Yu}(2012)$ & $\begin{array}{l}\text { A success model on project management information system PMIS based on survey of } \\
\text { experts in ERP implementation. }\end{array}$ \\
\hline Tatari and Skibniewski (2011) & $\begin{array}{l}\text { A statistical analysis to quantify the critical success factors (CSFs) that impact construction } \\
\text { enterprise information systems. }\end{array}$ \\
\hline Méxas and Quelhas (2012) & A survey to identify the most common used ERP selection criteria. \\
\hline Huang and Fisher (2005) & $\begin{array}{l}\text { A selection model based on TPC (technology, process and culture) as the main criteria classes } \\
\text { for ERP selection. }\end{array}$ \\
\hline Içtenbas et al. (2012) & A selection model for ERP modules based on QFD (quality function deployment) in Turkey. \\
\hline Chung et al. (2009) & A success model for ERP implementation based on critical success factors (CSFs). \\
\hline Wei (2008) & $\begin{array}{l}\text { A conceptual model for assessing the performance of an adopted ERP system in a } \\
\text { manufacturing environment. }\end{array}$ \\
\hline Mukti et al. (2014) & A conceptual model integrating success factors and success indicators in ERP implementation. \\
\hline Voordijk et al. (2003) & A case study on the selection of ERP system in large Dutch construction firm. \\
\hline Mohandas et al. (2013) & $\begin{array}{l}\text { A survey study to evaluate relevancy of ten success factors of ERP implementation in } \\
\text { construction firms. }\end{array}$ \\
\hline Mabert et al. (2003) & A big-bang approach (ERP package with all its modules) are implemented at one time. \\
\hline Hallikainen et al. (2009) & A framework to guide companies in prioritizing ERP modules implementation. \\
\hline Ghosh and Skibniewski (2010) & $\begin{array}{l}\text { A focus study on the critical success factors (CSF) and risk factors (RF) to help organizations } \\
\text { in ERP implementation. }\end{array}$ \\
\hline Zeng and Skibniewski (2013) & $\begin{array}{l}\text { A probabilistic risk assessment approach for ERP system implementation projects based on } \\
\text { fault tree analysis. }\end{array}$ \\
\hline Negahban et al. (2012) & $\begin{array}{l}\text { A study on the Small- to Mid-Size Construction Organizations (SMSCOs) organizations } \\
\text { potential to fail ERP implementation. }\end{array}$ \\
\hline Chung et al. (2008) & $\begin{array}{l}\text { A study on critical factors that need to be considered to ensure successful ERP system } \\
\text { implementation in the construction industry. }\end{array}$ \\
\hline
\end{tabular}

construction industry gained large expertise from the international construction practices and conversely, the international companies can also gain expertise from Saudi construction environment. In fact, many of the major Saudi construction companies are in the process of ERP acquisition to enhance their practices. The semistructured interview is best used when the interviewer won't get more than one opportunity to meet with the interviewee. It enables the respondent to clarify any ambiguity in the questionnaire. It also enables the researcher to elaborate more on specific questions that might be important to the research topic. The interview started with introduction of the subject, then a questionnaire is presented and explained to interviewee. The respondents are from wellknown construction companies in Saudi Arabia. This research approached grade I (largest companies) contracting companies in Saudi Arabia as classified by MOMRA (ministry of municipality and rural affairs, Saudi Arabia). The grade 1 contractors in the eastern province, Saudi Arabia are twenty three. Thirteen construction companies 


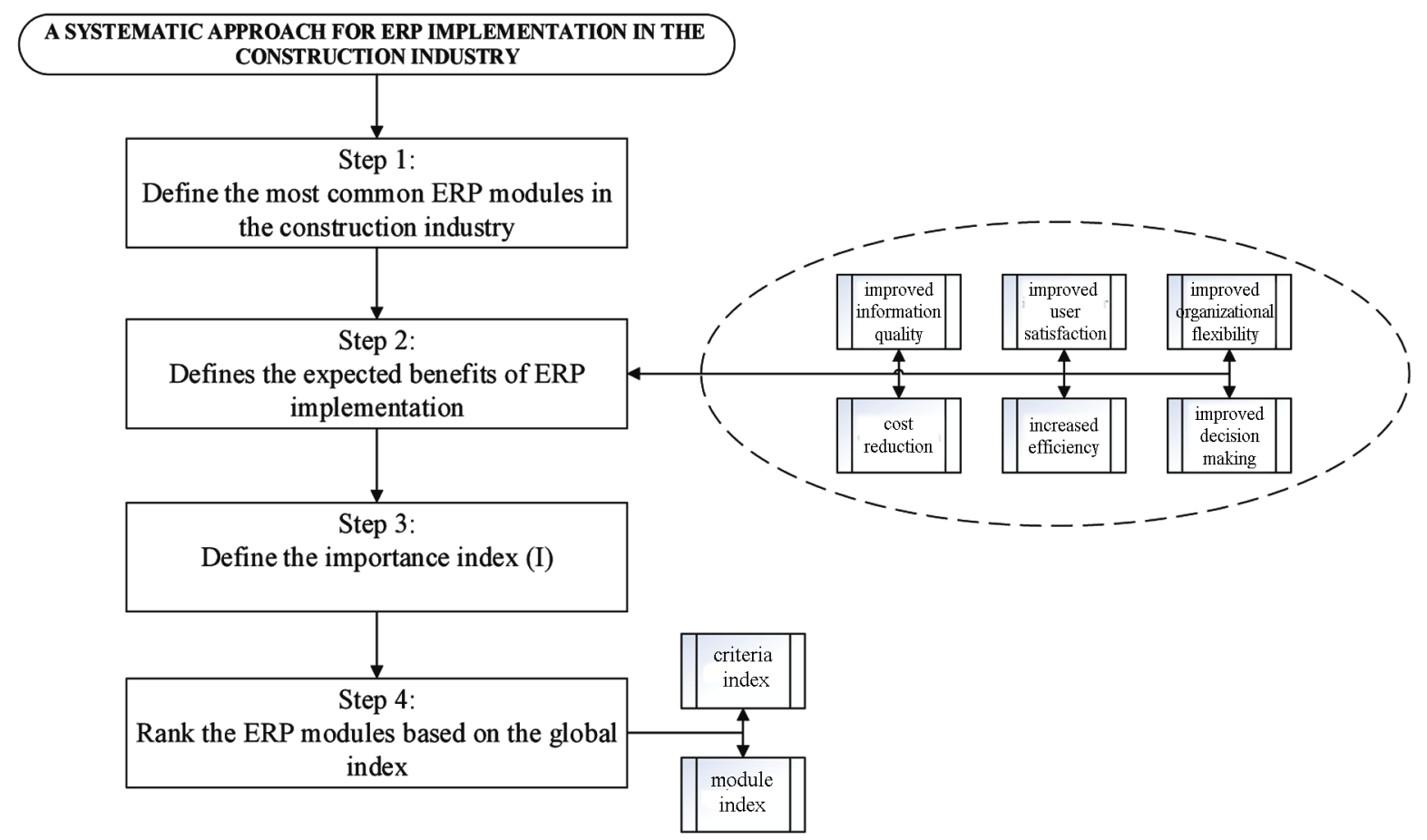

Fig. 1. Research methodology

of grade I only, have implemented successfully the ERP systems. The research team approached the whole population (grade I contractors with ERP systems) and seven of them were willing to participate in the research which compose 53\% (7 out of 13) of the population (thirteen grade 1 classification with ERP systems) in eastern province, Saudi Arabia.

\subsection{Step 1: Identify common-used ERP Modules in construction}

The research started with a twelve ERP modules defined by Chung and Skibniewski (2007) as a possible ERP modules for construction companies, namely: change management, project data management, project contract management, project collaboration, resources management, subcontract management, project costing, project billing, inventory control, purchasing, human resources, and Time \& Labor. The previous modules were reviewed by the research team and ERP experts during the interviews. The comprehensive list of the modules were developed based on the expertise of the interviewed ERP managers. The research team revised the ERP modules into thirteen modules, namely: 1 - Sales and Marketing; 2 - Human Resources; 3 - Tendering/bid management; 4 - Resource management; 5 - Data/document management; 6 - Collaboration; 7 - Contract and Change management; 8 - Project management and Budgeting; 9 - Subcontractor management; 10 - Time, expenses \& invoicing; 11 - Project Finance and accounting; 12 - Procurement; 13 - Inventory control and logistics.

\subsection{Step 2: Benefit Sub-Criteria Weights}

The ranking of EPR modules is based on scoring inputs of respondents as shown in Figure 2. Each respondent will evaluate the importance of each benefit criteria on a scale from 1 to 9 (highest score).

The collected data was analyzed using an importance index. The importance index (I) was computed by Eqn (1) (Assaf et al. 1995) where sixty three is the highest count can be achieved if all the respondents (seven) scored the highest possible weight which is (nine). Eqn (1) is used by several researchers to show the overall average of respondents rating as a percentage (Holt 2013):

$$
I=\sum_{i=1}^{9} \frac{a_{i} x_{i}}{63}
$$

where $I$ - importance index; $a_{i}$ - constant expressing the weight of the $i^{\text {th }}$ response, where $a_{i}=0,1,2, \ldots, 9$ for $i=1,2,3, \ldots, 9$ respectively; $x_{i}$ - frequency of the $i^{\text {th }}$ response given as a percentage of the total responses for each ERP module; $i$ - response category index where $i=1,2, \ldots, 9$.

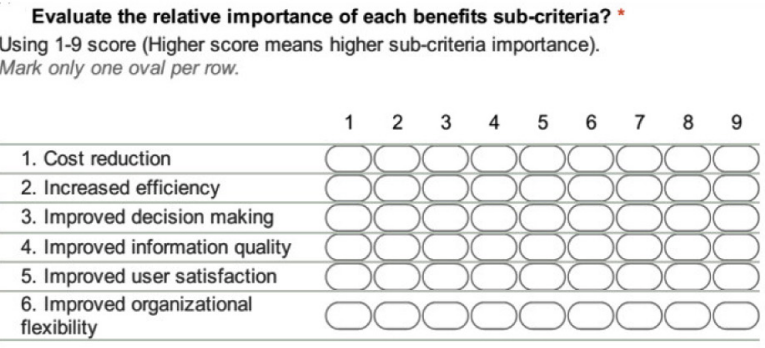

Fig. 2. Benefits ranking 
Table 2. Criteria index

\begin{tabular}{|c|c|c|c|c|c|c|c|c|c|}
\hline & & & & & & & & & \\
\hline & \multicolumn{9}{|c|}{ Rank Count } \\
\hline & 1 & 2 & 3 & 4 & 5 & 6 & 7 & 8 & 9 \\
\hline Cost Reduction & & & & 1 & & 2 & 2 & 1 & 1 \\
\hline Increased efficiency & & & 1 & & & & 3 & 1 & 2 \\
\hline Improved decision making & & & & & & 1 & 1 & 1 & 4 \\
\hline Improved information quality & & 1 & & & & 1 & 1 & 1 & 3 \\
\hline improved user's satisfaction & & 1 & 1 & & 1 & 1 & 1 & 1 & 1 \\
\hline improved organizational flexibility & & & 1 & & & 2 & 1 & 2 & 1 \\
\hline
\end{tabular}

\begin{tabular}{|c|}
\hline Importance Index \\
\hline $74.60 \%$ \\
\hline $79.37 \%$ \\
\hline $90.48 \%$ \\
\hline $79.37 \%$ \\
\hline $63.49 \%$ \\
\hline $74.60 \%$ \\
\hline 4.619047619 \\
\hline
\end{tabular}

For example: cost reduction criterion has one respondent who gave it rank 4, two respondents gave it rank 6 , two respondents gave it rank 7 , one respondents gave it rank 8, and one respondent gave it rank 9. The importance index for cost reduction criteria is equal to:

$$
\begin{aligned}
& I(\text { Cost Reduction })= \\
& \quad \frac{\sum_{i=1}^{9} a_{i} x_{i}}{63}=\frac{4 \times 1+6 \times 2+7 \times 2+8 \times 1+9 \times 1}{63}=74.6 \% .
\end{aligned}
$$

Respondents' score inputs for benefit sub-criteria are used to calculate their weights using Eqn (1). In Table 2, the weight distribution for every benefit sub-criteria for the seven respondents is given.

Improved decision making sub-criteria has the highest index $(90.48 \%)$, then in order, increased efficiency, improved information quality, cost reduction, improved organizational flexibility. Lastly, improved user satisfaction has the lowest average (lowest importance).

\subsection{Step 3: Evaluate ERP Modules on benefit criteria}

The questionnaire proceeds to collect the ranking of the thirteen modules for each benefit. For each benefit criteria, the thirteen module will be ranked similar to the way the benefits were ranked. Figure 3 shows the modules evaluation against each criteria.

Tables 3 and 4 show the weighted count for ERP modules under the six benefits criteria. Higher ranking number means higher benefit of the module compared to others.

\subsection{Step 4: Find the overall ranking of ERP Modules}

The overall rank of the ERP module will be found as shown in Eqn (2). This global index is created as an index which shows the multiplication of the importance indices of ERP modules and selection criteria in one index. The multi criteria ranking can be achieved of the thirteen ERP modules.

Global Index $=\sum_{i=1}^{6}($ Module Index $\times$ Criteria Index $)$.

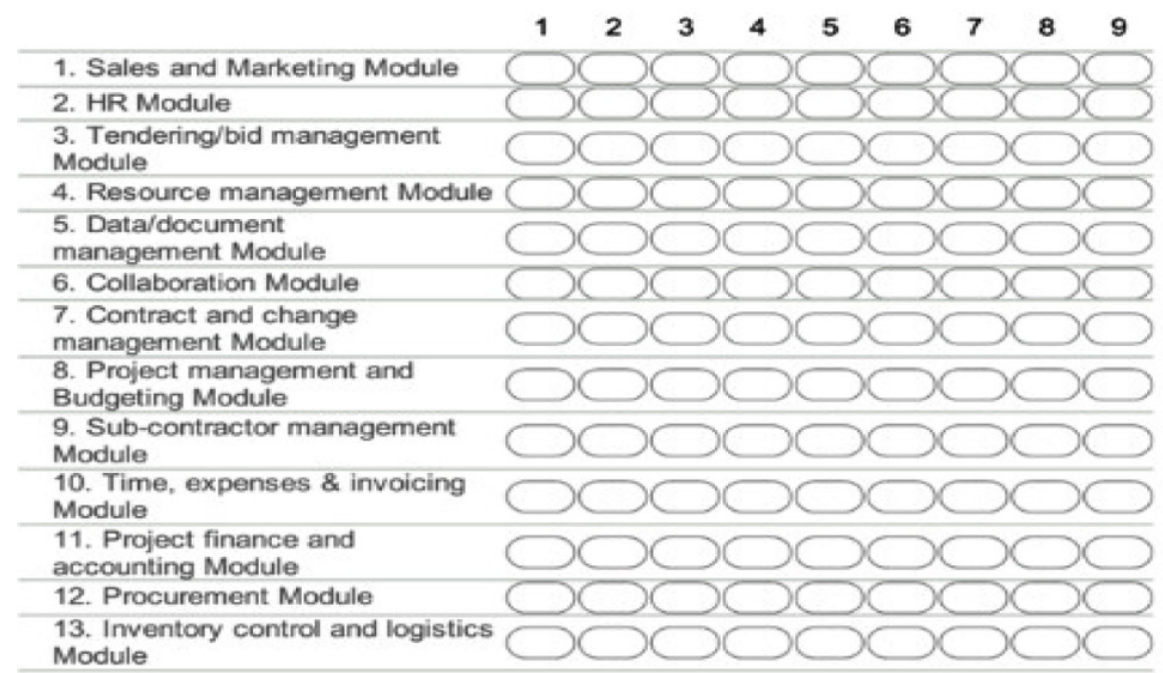

Fig. 3. Modules' evaluation for each benefit 
Table 3. Modules' index for benefits cost reduction, increased efficiency and improved decision making

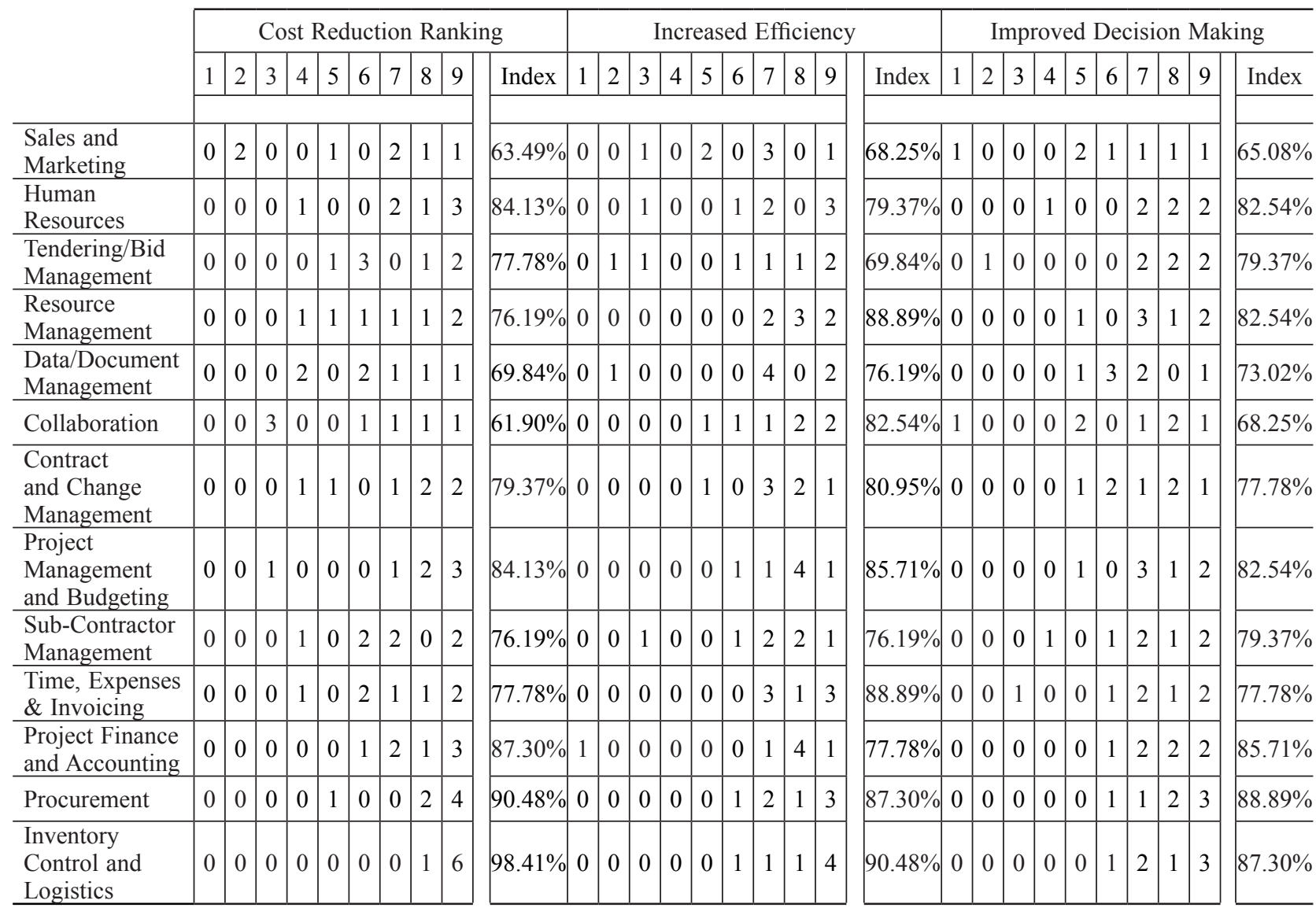

Table 4. Modules' index for benefits: improved information quality, users' satisfaction, and organizational flexibility

\begin{tabular}{|c|c|c|c|c|c|c|c|c|c|c|c|c|c|c|c|c|c|c|c|c|c|c|c|c|c|c|c|c|c|}
\hline & \multicolumn{10}{|c|}{ Improved Information Quality } & \multicolumn{9}{|c|}{ Improved User Satisfaction } & \multicolumn{10}{|c|}{ Improved Organizatiuonal Flexibility } \\
\hline & 1 & 2 & 3 & 4 & 5 & 6 & 7 & 8 & 9 & Index & 1 & 2 & $3 \mid$ & 4 & 5 & $6 \quad 7$ & $7 \quad 8$ & 9 & & 1 & 2 & 3 & 45 & $5 \mid 6$ & $6 \quad 7$ & 78 & 8 & 9 & Index \\
\hline & & & & & & & & & & & & & & & & & & & & & & & & & & & & & \\
\hline & 0 & 0 & 1 & 0 & 2 & 0 & 3 & 0 & 1 & $\%$ & 0 & 2 & $\begin{array}{lll}0 & 0\end{array}$ & 0 & 3 & \begin{tabular}{l|l}
0 & 1 \\
\end{tabular} & \begin{tabular}{l|l}
1 & 0
\end{tabular} & 1 & $5.56 \%$ & 0 & 1 & 0 & 03 & $3 \mid 0$ & $0 \mid 2$ & 20 & 0 & & $3.49^{\circ}$ \\
\hline- & 0 & 0 & r & 0 & & 0 & & 2 & & $\%$ & 0 & 1 & 0 & & 2 & \begin{tabular}{l|l}
0 & 1 \\
\end{tabular} & 1 & 2 & $\%$ & 0 & 1 & 0 & 0 & 2 & 2 & 1 & 1 & & 3.25 \\
\hline & 0 & 0 & 0 & 0 & 2 & 0 & 2 & 1 & 2 & $79.37 \%$ & 0 & 1 & 0 & 2 & 1 & 1 & & 1 & $8.73 \%$ & 1 & 1 & 0 & 02 & $2 \mid 0$ & 02 & 20 & 0 & & $7.14 \%$ \\
\hline & 0 & 0 & 0 & 1 & 3 & 0 & 1 & 0 & 2 & $84 \%$ & 0 & 1 & 0 & 0 & 3 & \begin{tabular}{l|l}
1 & 1
\end{tabular} & $1 \mid 0$ & ) 1 & $.90 \%$ & 0 & 0 & 0 & 0 & \begin{tabular}{l|l}
1 & 1
\end{tabular} & 14 & 40 & 0 & 1 & $6.19 \%$ \\
\hline & 0 & 0 & 0 & 1 & 1 & 1 & 2 & 1 & 1 & $73.02 \%$ & 0 & 0 & 1 & 0 & 1 & \begin{tabular}{l|l}
2 & 1
\end{tabular} & $1 \mid 0$ & 2 & $1.43 \%$ & 0 & 0 & 1 & 1 & $1 \mid 1$ & 12 & 20 & 0 & 1 & $55.08 \%$ \\
\hline & 1 & 0 & & 0 & & 0 & & & & $3.02 \%$ & 0 & T & 0 & & 2 & \begin{tabular}{l|l}
1 & 2 \\
\end{tabular} & 2 & 2 & $9 \%$ & 0 & \begin{tabular}{l|l}
0 \\
\end{tabular} & 0 & 0 & \begin{tabular}{l|l}
2 & 1 \\
\end{tabular} & \begin{tabular}{l|l}
1 & 2 \\
\end{tabular} & \begin{tabular}{l|l}
2 & 1
\end{tabular} & 1 & & $4.60^{\circ}$ \\
\hline & 0 & 0 & 0 & 1 & 0 & 1 & 1 & 1 & 3 & & 0 & 0 & 0 & 1 & 3 & 5 & 0 & 1 & $7 \%$ & 0 & 0 & 1 & \begin{tabular}{l|l}
0 & 2
\end{tabular} & $2 \mid 0$ & 03 & 3 & v & 1 & $5 \%$ \\
\hline & 0 & 0 & 0 & 0 & 0 & 1 & 3 & 1 & 2 & $3 \%$ & 0 & 0 & 0 & 1 & 1 & $1 \mid 1$ & 1 & $\begin{array}{ll}2 & 1\end{array}$ & $60 \%$ & 0 & 0 & 0 & $1 \mid 1$ & $1 \mid 1$ & 12 & 20 & 0 & & $0 \%$ \\
\hline & 0 & 0 & 0 & 0 & 0 & 1 & 3 & 1 & 2 & $.13 \%$ & 0 & 0 & 0 & 0 & 2 & \begin{tabular}{l|l}
2 & 1
\end{tabular} & 1 & $1 \quad 1$ & $02 \%$ & 0 & 0 & 0 & \begin{tabular}{l|l}
1 & 1
\end{tabular} & 12 & $2 \mid 2$ & 20 & 0 & 1 & $9.84 \%$ \\
\hline & 0 & 0 & 1 & 0 & 0 & 0 & 2 & 2 & 2 & $30.95 \%$ & 0 & 0 & 0 & 0 & 3 & 10 & 0 & 21 & $3.02 \%$ & 0 & 0 & 0 & \begin{tabular}{l|l}
0 & 1
\end{tabular} & 10 & \begin{tabular}{l|l}
0 & 1
\end{tabular} & 1 & 4 & & $3 \%$ \\
\hline & 0 & 0 & 0 & 0 & 0 & 0 & 2 & 3 & 2 & 88 & 0 & 0 & 0 & 0 & 3 & \begin{tabular}{l|l}
0 & 1
\end{tabular} & 1 & 21 & $60 \%$ & 0 & 0 & 0 & $1 \mid 1$ & 10 & \begin{tabular}{l|l}
0 & 1
\end{tabular} & 13 & 3 & 1 & $78 \%$ \\
\hline & 0 & 0 & 0 & 0 & 2 & 0 & 1 & 1 & 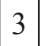 & $82.54 \%$ & 0 & 10 & 0 & 1 & 2 & \begin{tabular}{l|l}
0 & 1
\end{tabular} & 1 & 21 & $02 \%$ & 0 & 0 & 0 & \begin{tabular}{l|l}
0 & 1
\end{tabular} & \begin{tabular}{l|l}
1 & 1
\end{tabular} & \begin{tabular}{l|l}
1 & 1
\end{tabular} & 12 & 2 & & $2.54 \%$ \\
\hline & 0 & 0 & 0 & 0 & 2 & 0 & 1 & 1 & J & $82.54 \%$ & 0 & 0 & 0 & 0 & 2 & 20 & \begin{tabular}{l|l}
0 & 2
\end{tabular} & \begin{tabular}{l|l}
2 & 1
\end{tabular} & $74.60 \%$ & 0 & 0 & 0 & 0 & \begin{tabular}{l|l}
0 & 2
\end{tabular} & $2 \mid$ & 12 & 2 & 2 & . \\
\hline
\end{tabular}


Table 5 shows the final ranking of ERP modules based on their overall weight.

Table 5. Modules' global index

\begin{tabular}{cll}
\hline Rank & \multicolumn{1}{c}{ ERP Module } & Global Index \\
\hline 1 & Inventory Control and Logistics & 3.99848828 \\
2 & Procurement & 3.90652557 \\
3 & Project Finance and Accounting & 3.80347695 \\
4 & Project Management and Budgeting & 3.75258251 \\
5 & Time, Expenses \& Invoicing & 3.72310406 \\
6 & Human Resources & 3.63466868 \\
7 & Sub-Contractor Management & 3.54346183 \\
8 & Resource Management & 3.53640716 \\
9 & Contract and Change Management & 3.52582514 \\
10 & Collaboration & 3.3542454 \\
11 & Data/Document Management & 3.30486269 \\
12 & Tendering/Bid Management & 3.28168304 \\
13 & Sales and Marketing & 2.97228521 \\
\hline
\end{tabular}

\section{Conclusions}

The provided research is the first attempt to address the ERP implementation in the Saudi construction industry. The state of technology in the Saudi construction market is up to the highest international standards. The findings of this research helps Saudi construction companies to have a successful ERP acquisition and implementation. It also provides a systematic approach to rank ERP modules for construction companies in different parts of the world. Interested companies can implement the procedure in their own business environment and get different ranking that suits their specific needs. The ERP implementation for construction industry received high momentum of research pursued by the fact that such implementation is characterized by risks of failure. Therefore, new approaches to better manage the ERP implementation is highly welcomed by construction companies as it helps them to minimize the risk of failure and maximize their benefits of implementation. The provided approach of this research helps construction companies worldwide and specifically Saudi Arabia to better implement ERP projects.

A newly defined four step methodology is followed in this paper to sequence the ERP module implementation for construction firms. The approach includes the following steps: first step defines the most common ERP modules in the construction industry which can be easily customised to the specific needs for companies worldwide. The second step defines the expected benefits of ERP implementation. These benefits include: cost reduction, increased efficiency, improved decision making, improved information quality, improved user satisfaction, and improved organizational flexibility. The mentioned benefits were collected based on the available literature of ERP implementation worldwide. The third step defined the importance index (I) for the six benefits based on the responses of the firms under study. This index might vary one company to another which provides a reasonable level of flexibility of the proposed methodology. Finally, the fourth step rank the ERP modules based on the global index that combines the criteria index and module index. The collected data were based on seven of the largest construction companies in eastern province in Saudi Arabia. Out of thirteen modules, the top ranked modules were inventory control and logistics, procurement, and project finance and accounting. The findings of the paper would help construction firms to prioritize the acquisition of different ERP modules and can be easily adjusted to their specific needs.

\section{Acknowledgements}

The authors thank King Fahd University of Petroleum and Minerals for the support and facilities that made this research possible. The authors also would like to acknowledge the anonymous reviewers for their constructive comments that improved the content of this paper.

\section{References}

Arnold, P.; Javernick-Will, A. 2013. Project wide access: Key to effective implementation of construction project management software systems, Journal of Construction Engineering and Management 139(5): 510-518. https://doi.org/10.1061/(ASCE)CO.1943-7862.0000596

Assaf, S.; Al-Khalil, M.; Al-Hazmi, M. 1995. Causes of delay in large building construction projects, Journal of Management in Engineering 11(2): 45-50. https://doi.org/10.1061/(ASCE)0742-597X(1995)11:2(45)

Chung, B. Y.; Skibniewski, M. 2007. Cost-benefit analysis of ERP modules in construction firms, AACE International Transactions, IT71.

Chung, B. Y.; Skibniewski, M. J.; Lucas, H. C.; Kwak, Y. H. 2008. Analyzing enterprise resource planning system implementation success factors in the engineering construction industry, Journal of Computing in Civil Engineering 22(4): 373-382.

https://doi.org/10.1061/(ASCE)0887-3801(2008)22:6(373)

Chung, B.; Skibniewski, M.; Kwak, Y. 2009. Developing ERP systems success model for the construction industry, Journal of Construction Engineering Management 135(3): 207-216. https://doi.org/10.1061/(ASCE)07339364(2009)135:3(207)

Dezdar, S.; Ainin, S. 2011. Measures of success in projects implementing enterprise resource planning, International Journal of Business Performance Management 12(4): 334-353. https://doi.org/10.1504/IJBPM.2011.042012

Ghosh, S.; Skibniewski, M. 2010. Enterprise resource planning systems implementation as a complex project: a conceptual framework, Journal of Business Economics and Management 11(4): 533-549. https://doi.org/10.3846/jbem.2010.26

Ehiea, I.; Madsenb, M. 2005. Identifying critical issues in enterprise resource planning (ERP) implementation, Computers in Industry 56(6): 545-557. https://doi.org/10.1016/j.compind.2005.02.006

Hallikainen, P.; Kivijärvi, H.; Tuominen, M. 2009. Supporting the module sequencing decision in the ERP implementation process - an application of the ANP method, International Journal of Production Economics 119(2): 259-270. https://doi.org/10.1016/j.ijpe.2009.03.008 
Holt, G. 2013. Asking questions, analysing answers: relative importance revisited, Construction Innovation 14(1): 2-16. https://doi.org/10.1108/CI-06-2012-0035

Huang, C.; Fisher, N. 2005 An alternative methodology for selecting enterprise resource planning (ERP) systems in a typical architecture/engineering/construction (AEC) company, International Journal of Construction Management 5(1): 39-57. https://doi.org/10.1080/15623599.2005.10773066

Içtenbas, B. D.; Rouyendegh, B. D.; Erkan, T. E. 2012. Selection of ERP system using QFD approach: a pilot study from Turkey, in International Conference on Information Management and Evaluation, 2012, Antara, Turkey. Academic Conferences International Limited, Reading.

Isikdag, U.; Underwood, J.; Kuruoglu, M.; Acikalin, U. 2013. Data integration capability evaluation of ERP systems, International Journal of Enterprise Information Systems 9(3): 113-129. https://doi.org/10.4018/jeis.2013070106

Karimi, J.; Somers, T. M.; Bhattacherjee, A. 2007. The impact of ERP implementation on business process outcomes: A factor-based study, Journal of Management Information Systems 24(1): 101-134. https://doi.org/10.2753/MIS0742-1222240103

Lee, S.-K.; Yu, J.-H. , 2012. Success model of project management information system in construction, Automation in Construction 25: 82-93. https://doi.org/10.1016/j.autcon.2012.04.015

Lu, Y.; Li, Y.; Skibniewski, M.; Wu, Z.; Wang, R.; Le, Y. 2014. Information and communication technology applications in architecture, engineering, and construction organizations: A 15-year review, Journal of Management in Engineering 31(1): 1943-5479.

Mabert, V. A.; Soni, A.; Venkataramanan, M. A. 2003. Enterprise resource planning: managing the implementation process, European Journal of Operational Research 146(2): 302-314. https://doi.org/10.1016/S0377-2217(02)00551-9

Méxas, M. P.; Quelhas, O. L. G. 2012. Prioritization of enterprise resource planning systems criteria: focusing on construction industry, International Journal of Production Economics 139(1): 340-350. https://doi.org/10.1016/j.ijpe.2012.05.025

Méxas, M. P.; Quelhas, O. L. G.; Costa, H. G. 2012. Prioritization criteria for enterprise resource planning systems selection for civil construction companies: a multicriteria approach, Canadian Journal of Civil Engineering 39(8): 855-866. https://doi.org/10.1139/12012-071

Mohandas, P.; Piyush, D.; Pataskar, S. V.; Muralidharan, U. 2013. Research analysis for successful functioning of ERP system in construction industry, International Journal of Engineering Research \& Technology (IJERT) 2(11).

Mukti, S. K.; Tripathi, P.; Rawani, A. M. 2014. Identification of factors and indicators for success measurement of ERP system. Singapore: IACSIT Press.
Nazemi, E.; Tarokh, M. J.; Djavanshir, G. R. 2012. ERP: a literature survey, The International Journal of Advanced Manufacturing Technology 61(9): 999-1018. https://doi.org/10.1007/s00170-011-3756-x

Negahban, S.; Baecher, G.; Skibniewski, M. 2012. A decisionmaking model for adoption of enterprise resource planning tools by small-to-medium size construction organizations, Journal of Civil Engineering and Management 18(2): 253-264. https://doi.org/10.3846/13923730.2012.666503

Olhager, J.; Selldin, E. 2003. Enterprise resource planning survey of Swedish manufacturing firms, European Journal of Operational Research 146(2): 365-373. https://doi.org/10.1016/S0377-2217(02)00555-6

Ozorhon, B.; Cinar, E. 2015. Critical success factors of enterprise resource planning implementation in construction: case of Turkey, Journal of Management in Engineering 31(6), number 04015014.

Ram, J.; Wu, M.-L.; Tagg, R. 2014. Examining the role of key implementation drivers, International Journal of Project Management 32(4): 663-675.

https://doi.org/10.1016/j.ijproman.2013.08.004

Skibniewski, M. J.; Ghosh, S. 2009. Determination of key performance indicators with enterprise resource planning systems in engineering construction firms, Journal of Construction Engineering and Management 135(10): 965-978.

https://doi.org/10.1061/(ASCE)0733-9364(2009)135:10(965)

Tambovcevs, A. 2012. ERP system implementation in Latvian manufacturing and construction company, Technological and Economic Development of Economy 18(1): 67-83. https://doi.org/10.3846/20294913.2012.661176

Tatari, O.; Skibniewski, M. J. 2011. Empirical analysis of construction enterprise information systems: assessing system integration, critical factors, and benefits, Journal of Computing in Civil Engineering 25(5): 347-356. https://doi.org/10.1061/(ASCE)CP.1943-5487.0000096

Voordijk, H.; Van Leuven, A.; Laan, A. 2003. Enterprise resource planning in a large construction firm: implementation analysis, Construction Management and Economics 21(5): 511-521. https://doi.org/10.1080/0144619032000072155

Wei, C. C. 2008. Evaluating the performance of an ERP system based on the knowledge of ERP implementation objectives, The International Journal of Advanced Manufacturing Technology 39 (1-2): 168-181. https://doi.org/10.1007/s00170-007-1189-3

Yang, J.; Wu, C.; Tsai, C. 2007. Selection of an ERP system for a construction firm in Taiwan: a case study, Automation in Construction 16(6): 787-796. https://doi.org/10.1016/j.autcon.2007.02.001

Yin, R. K. 2003. Case study research: design and methods. $3^{\text {rd }}$ ed. Thousand Oaks, CA: Sage Publications.

Zeng, Y.; Skibniewski, M. 2013. Risk assessment for enterprise resource planning (ERP) system implementations: a fault tree analysis approach, Enterprise Information Systems 7(3): 332-353. https://doi.org/10.1080/17517575.2012.690049

Laith A. HADIDI. Dr. Is an assistant professor in the Department of Construction Engineering and Management at King Fahd University of Petroleum and Minerals in Dhahran, Saudi Arabia, since 2013. His research interests include: scheduling; quality assurance and control; maintenance engineering; and management optimization of quality and maintenance systems. Dr Hadidi gained his $\mathrm{PhD}$ in Industrial and Systems Engineering in 2011 from the King Fahd University of Petroleum and Minerals in Dhahran, Saudi Arabia.

Sadi ASSAF. Dr. Is a professor in the Department of Construction Engineering and Management at King Fahd University of Petroleum and Minerals in Dhahran, Saudi Arabia. His research interests include: quantitative methods in construction management, risk management in construction, value engineering, constructability, and safety. Dr Assaf gained his PhD in Civil Engineering, University of Illinois-Urbana, USA, 1982.

Adel ALKHIAMI. He is a master student in the Department of Construction Engineering and Management at King Fahd University of Petroleum and Minerals in Dhahran, Saudi Arabia. Mr. AlKhiami gained his Master of engineering degree in engineering management in 2015. 